\title{
EXTREME JULY PRECIPITATION AND ITS CONSEQUENCES ON CRNA TRAVA MUNICIPALITY, SERBIA
}

\author{
Marijana Petrović $c^{A, B^{*}}$, Renata Fekete ${ }^{A, B}$, Miloš Ostojićc $c^{A, B}$, Milica G. Radaković ${ }^{A, B}$ \\ Received: September 12, 2019 | Accepted: December 27, 2019 \\ DOI: 10.5937/ZbDght1902112P
}

\begin{abstract}
Even though climate variability, geology, and human activity are main triggers of landslides, based on earlier research, precipitation is considered the most important natural factor responsible for soil erosion in the landslide context. In this study landslide activation has been correlated with precipitation in least developed municipality of Crna Trava located in South-east Serbia. The purpose of this study is analyzing the precipitation in thirteen surrounding settlements: Vranje, Leskovac, Babušnica, Bela Palanka, Pirot, Dimitrovgrad, Kalna, Kriva Feja, Vladičin Han, Vučje, Vlasotince, Grdelica, Brestovac and finding its correlation to landslide occurrences. Precipitation for seven decades (period 1946-2017) has been interpolated by IDW method in the software ArcMap 10.5 and correlated to Crna Trava slope map. Potential locations of landslides were determined and compared to the recent landslides which occurred in July in 2018, in Bankovci village. Potential years for landslide activation were compared to calculated values of The Precipitation Concentration Index (PCI), The Modified Fournier Index (MFI), and Lang Aridity Index ( $\left.A I_{\text {Lang }}\right)$. The case study was done based on fieldwork which happened in a period from 20 to 26 of July 2018 in the village of Bankovci. On the 25 of July landslides were activated because of the extreme weather conditions, which affected wider region in Central and South-east Serbia: 100 liters of rain fell during the three-hour period. Habitants were interviewed about their memories on extreme floods and landslides in Crna Trava municipality, and the years they mentioned are in well agreement with our results of the extreme precipitation events.
\end{abstract}

Keywords: precipitation, landslides, aridity index, south-east Serbia, hazards

A Young researchers' society "Branislav Bukurov", Faculty of Sciences, University of Novi Sad, Trg Dositeja Obradovića 3, Novi Sad 21000, Serbia

B Department of Geography, Tourism and Hotel management, Faculty of Sciences, University of Novi Sad, Trg Dositeja Obradovića 3, Novi Sad 21000, Serbia

* Corresponding author: dgt.marijana.petrovic@student.uns.ac.rs 


\section{INTRODUCTION}

Landslides are connotated as one of the biggest problems of modern world and natural hazards of 21st century. Thus, they became a topic of major interest not only for geoscientist but also for local communities, as they have socio-economic significance (Aleotti, Chowdhury, 1999). It can be conditionally said that almost every country faces this problem in certain critical areas, in smaller or larger proportions, and has its own ways of controlling this problem. This means landslides occurrence is a problem with global meaning and it affects humanity in many certain ways. The number of fatalities due to landslides and damaged households can serve as precise indicators for determining a countries vulnerability to this hazard.

Landslides can cause casualties, but these are not so common. According to Vernes (1981) about 600 people have lost their lives every year from 1971-1974 as a consequence of slope destabilization. The most catastrophic landslide in Europe occurred in Italy in the last century, and it had almost 2000 victims (Aleotti, Chowdhury, 1999). Between 2004 and 2010, 2620 landslides killed a total of 32322 people worldwide - a number which doesn't even include those caused by earthquakes (Petley, 2012).The Global Landslide Model which tracks recent rainfall and after checking recorded information about the susceptibility of terrain in each area, determined the likelihood of landslides occurrence, and was developed by Kirschbaum and Stanley (2018). The criteria they have been using is whether or not the roads have been built, whether trees have been cut down, whether a major tectonic fault is nearby, the state of the local bedrock, and - the most important factor - the steepness of hillsides. There is a large number of constantly active and under controlled landslides. Local administrations apply certain security measures that temporarily stop the problem and protect the populated areas and high traffic routes from this type of accident.

Fig 1 shows modified map of Europe with the location of Serbia, as well as municipality of Crna Trava. It can be seen that all the landslide susceptibility levels are present in Serbia, especially in the southern, mountainous region. Even in the northern province

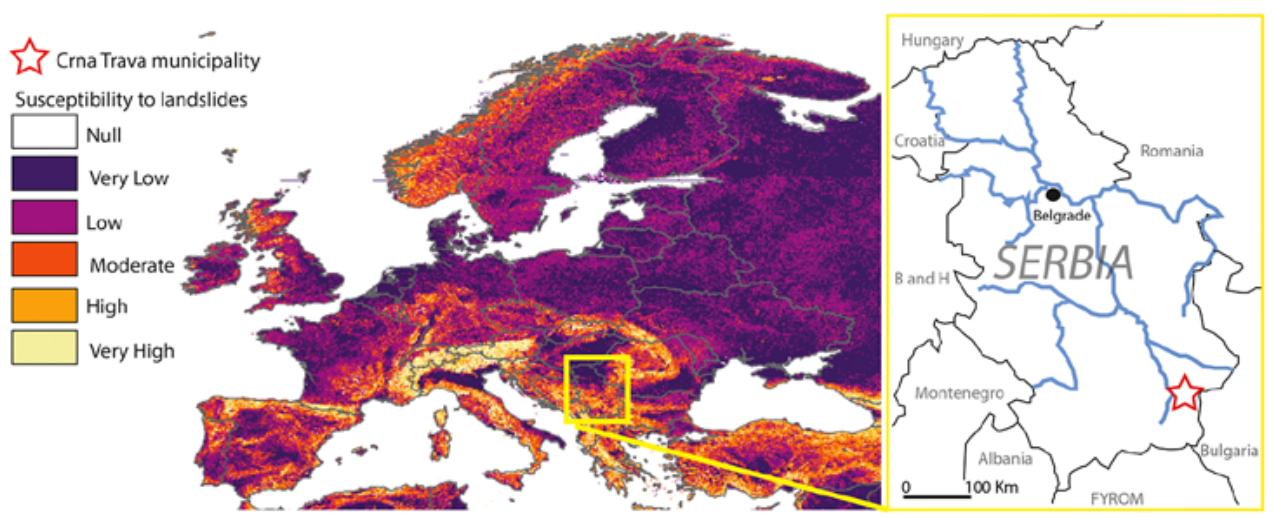

Figure 1. Map of Europe landslide susceptibility (Stanley, Kirschbaum, 2018, modified), and location of Crna Trava municipality in Serbia 
of Vojvodina in Carpathian basin there were active landslides (Abolmasov at al., 2015, Marjanović, 2009). Landslides in Serbia have been well studied (Lazarević, 2000, Lukić at al., 2018), and it has been determined that $15 \%$ of territory is affected by active, suspended and dormant landslides (Dragićević at al., 2011).

Countries confronted with this type of natural disasters have landslides "hot spots" which are constantly being remediated and monitored. Likewise, there are a large number of underdeveloped areas, often mountain regions with rural and old population that are not even equipped with adequate traffic issues. Habitants of Crna Trava municipality are related to a different way of life and they remain stationed in the place where they are located, regardless of consequences of weather variabilities. Those disasters aren't controlled and recorded. In Serbia, the most undeveloped municipality with the highest demographic catastrophe and population displacement is the municipality of Crna Trava. The municipality of Crna Trava counts 25 settlements and lies in the mountainous region between 346 and $1721 \mathrm{~m}$. According to the 2011 population census of Republic of Serbia (Census of Population, 2011), the total number of inhabitants was 1663. Fourteen out of twenty-five settlements have less than thirty inhabitants, while only four, including the only urban settlement town of Crna Trava, have over 100 inhabitants and an average population density of 4.07 per $\mathrm{km}^{2}$. From informal sources it is known that the total number of inhabitants on the municipality territory is reduced by almost $50 \%$, because eight years have passed from the last census, and the number is still decreasing because of migrations and natural population movement (Kitanović, 2015). Temperature changes manifested in the form of large precipitation, drought, snowstorms or floods with slopes and landslides therefore, also present a frequent occurrence in those areas. For those abandoned areas local authorities need a lot of time to reach information about any natural disaster which happened caused by weather variabilities. Fast intervention after natural disasters is impossible due to bad infrastructure of this municipality. On 25 of July, $100 \mathrm{~mm}$ of rain fell for three hours followed by many consequences on inhabitants' property. The research of the sensitivity of the area to weather variabilities is required.

\section{STUDY AREA}

The municipality of Crna Trava is located in the southeastern part of the Republic of Serbia. The geographical position of the municipality of Crna Trava can be characterized as relatively unfavorable because it also represents the border area. The municipality of Crna Trava is bordered with the Republic of Bulgaria on east part, on the north it borders with the municipalities of Babušnica and Vlasotince, on the west it borders with municipality of Leskovac, and in the southwest and south with municipalities Vladičin Han and Surdulica. The municipality of Crna Trava has a $4.2 \mathrm{~km}$ state border to Bulgaria. There are no official state border crossings on the territory of Crna Trava.

The disadvantage of the position is also due to the poor road connection with the major centers of this part of Serbia. The main road to the Crna Trava settlement was built in 1976. The only important links are the way to city of Leskovac via Vlasotince bearing 


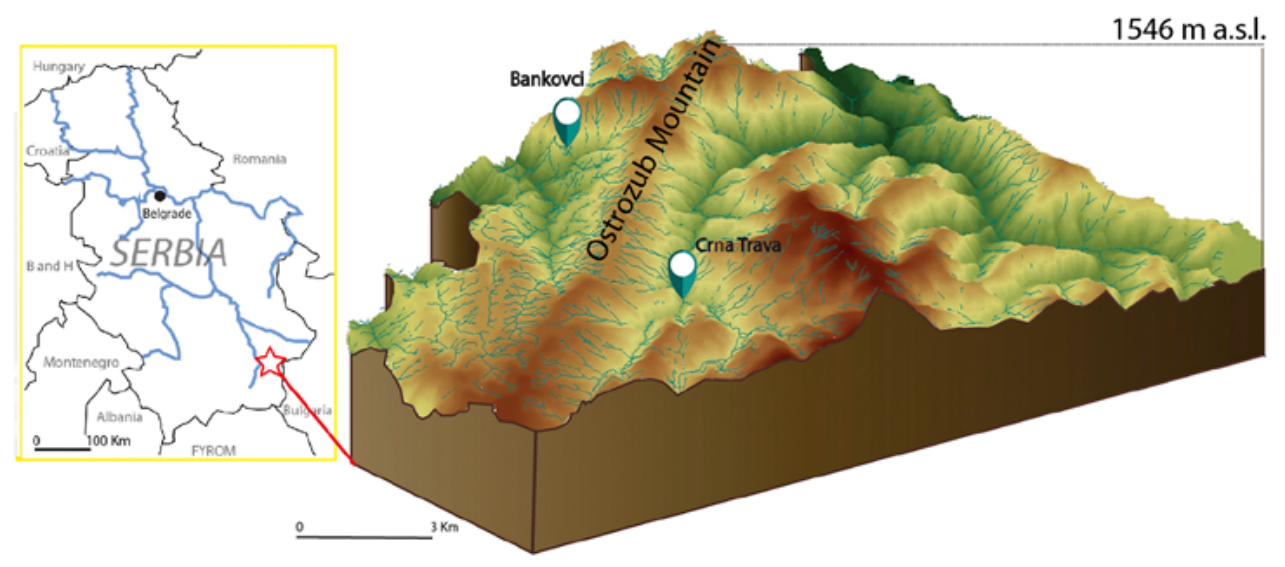

Figure 2. Digital Elevation Model of Crna Trava municipality and geographical position of city of Crna Trava,Bankovci village and Ostrozub Mountain.

the mark M-9 and the route to Vladicin Han through Vlasina and Surdulica (Marković, Pavlović, 1995). Municipality of Crna Trava covers an area of $312 \mathrm{~km}^{2}$. In the past, Crna Trava municipality had two main gravitational points. One of the current gravity centers is Leskovac and Niš, through Vlasotince, and the second was Bulgarian settlement Trn, which has now lost significance due to the state border and the reduction of the population of Crna Trava. The north and northwestern part of the municipality also maintains a connection with city of Pirot through city of Babušnica, although all are administratively addressed to city of Vlasotince. The city of Leskovac is $56 \mathrm{~km}$ away from city of Crna Trava. The biggest lake in this area of Serbia, called Vlasina Lake is only 10 $\mathrm{km}$ away from Crna Trava. The climate of this municipality is humid, with the mean annual temperature of $11^{\circ} \mathrm{C}$, and mean annual precipitation of $630 \mathrm{~mm}$ (Radaković at al., 2017). The Fig 2 displays advantage of the locations of Crna Trava and Bankovci village represented on DEM model and position of Crna Trava municipality shown on the map of Serbia.

\section{METHODOLOGY}

The methodology of this paper can be represented through its three integral parts, which are climatic analyses based on aridity indexes, ArcGIS analysis by software Arc Map 10.5 and fieldwork that preceded the development of this paper.

\section{Climatic Analyses}

The total amount of precipitation for the month July for the period from 1947 to 2017 was exposed to a detailed analysis. After finding critical years when the amount of precipitation in July had increased values, interpolation which involved data from 13 surrounding precipitation stations was done. Potential years for landslide activation were 
confirmed by using The Precipitation Concentration Index $(P C I)$ which characterizes rainfall variability through space and time (Apaydin at al., 2016, De Luis at al., 2009, De Luis at al., 2011). Formula used for this index is following:

$$
\text { PCI seasonal }=\frac{\sum_{i=1}^{3} P i^{2}}{\left(\sum_{i=1}^{3} P i\right)^{2}} \cdot 25
$$

Where $P i$ means monthly precipitation in $\mathrm{mm}$ for month $\mathrm{i}$.

Table 1. Values of The Precipitation Concentration Index (PCI)

\begin{tabular}{|l|c|}
\hline & Value of index \\
\hline Uniform & $\leq 10$ \\
\hline Moderate & $>10 \leq 15$ \\
\hline Irregular & $>15 \leq 20$ \\
\hline Strongly irregular & $>20$ \\
\hline
\end{tabular}

Table 1 represents the categories of this index.

Another index used in this study is the Modified Fournier Index (MFI) expressed by formula (Fournier, 1960):

$$
M F I=\sum_{i=1}^{12} \frac{p^{2}}{p}
$$

Where $p_{i}$ is mean monthly amount, $\mathrm{P}$ is annual rainfall amount (all in $\mathrm{mm}$ ) and $i$ is mark for the month.

Table 2: Values of Modified Fournier Index (MFI)

\begin{tabular}{|l|c|}
\hline & Value of index \\
\hline Very low & $0-60$ \\
\hline Moderate & $60-90$ \\
\hline High & $90-120$ \\
\hline Very high & $120-160$ \\
\hline
\end{tabular}

Table 2 presents the values of this index.

Lang Aridity Index (AiLang) works only when the Mean Annual Temperature (MAT) is above $0^{\circ} \mathrm{C}$ (Lang, 1920, Quan at al., 2013) because it stands as denominator. The other parameter used in formula is Mean Annual Precipitation (MAP), in mm:

$$
\text { AiLang }=\frac{M A P}{M A T}
$$


Data from three climatic stations are used to calculate these indices: Vranje, Leskovac and Babušnica.

Table 3: Values of Lang Aridity Index (AiLang)

\begin{tabular}{|l|c|}
\hline & Value of index \\
\hline Arid & $<40$ \\
\hline Humid & $40-160$ \\
\hline Per humid & $>160$ \\
\hline
\end{tabular}

Table 3 shows values of this index.

Data used for this study was provided by the Hydro-meteorological Service of Serbia and can be found in meteorological yearbooks (http://www.hidmet.gov.rs/ciril/meteorologija/klimatologija godisnjaci.php). Visualized results are shown in Fig 3.

\section{ArcGIS analyses}

Any analysis that examines the vulnerability of this area requires the digitization of the entire municipality. One of the most recognizable methods in analysis of landslides is digitization of spatial information (Van Westen at al., 2006). Digital Elevation Model was obtained based on digitization of isolines and elevation points from the topographic map of the Vlasotince section. 3D model of Crna Trava municipality was created by Arc Scene 10.5 software. Rivers are also digitized for the entire area of the Crna Trava municipality. Precipitation for seven decades (period 1946-2017), for month July has been interpolated by IDW method in the software ArcMap 10.5 and correlated to Bankovci village slope map. Due to some meteorological stations has stopped working after 2000's, extreme July precipitation has been interpolated for selected critical years with increased precipitation amount before 2000's which include: 1960, 1967, 1970, 1976, 1983, 1986 and 1991. Precipitation interpolation included data from thirteen surrounding precipitation stations: Vranje, Leskovac, Babušnica, Bela Palanka, Pirot, Dimitrovgrad, Kalna, Kriva Feja, Vladičin Han, Vučje, Vlasotince, Grdelica and Brestovac. Potential locations of landslides were determined and compared to the recent landslides which occurred in the end of July in 2018. Roads in village of Bankovci are digitalized based on topographic map from 1973 and compared with roads that exist now based on Google Earth Pro. Slope analysis are based on the example of the village of Bankovci, where landslides were triggered by weather fluctuations. Of the total length of the roads that existed in this settlement according to the topographic map of 1973 , about $46 \%$ of the roads have disappeared and a large part of these roads is in the potential landslide zones. About $45 \%$ of the roads that now exist in the area of this settlement are located in the potential zones of the landslides activation and it is represented with orange and red coloron the slope map shown in fig 9. Households in Bankovci village were also digitalized and the perceived vulnerability of households was calculated. With Corine Land Cover the percentage distribution of vegetation types was calculated. Data for the geological composition of the substrate were taken from geological map created by Ministry of Energy, Development and Environmental Protection of 
Republic of Serbia (http://geoliss.mre.gov.rs/OGK/RasterSrbija/). The geographical coordinates of landslides in Bankovci village were recorded by GPS and exported to Google Earth Pro by software GPS Babel, and then imported to ArcMap 10.5.

\section{Field work}

The fieldwork was held from 20 to 26 July 2018. The village of Bankovci represented a stationary and starting point for every research carried out in the municipality of Crna Trava. After extraction of a large amount of precipitation in the value of $100 \mathrm{~mm}$ in three hours on 25 July 2018, the effect and consequences were visible on July 26 th. The group of investigators visited places where the consequences were visible, collected photos of landslides, flash floods, destroyed roads, households, etc. New geomorphological features on slopes of Ostrozub mountain in Bankovci village created by extreme weather conditions were determined and measured.

\section{RESULTS AND DISCUSIONS}

It can be said that precipitation plays a major role in the context of landslide formation. The geological background, vegetation and slope of the terrain must accelerate this. There are thirteen surrounding precipitation stations: Vranje, Leskovac, Babušnica, Bela Palanka, Pirot, Dimitrovgrad, Kalna, KrivaFeja, Vladičin Han, Vučje, Vlasotince, Grdelica, Brestovac and only Kalna is located in Crna Trava municipality.

Extreme July precipitation from 1946 to 2017 has been interpolated by IDW method for critical years, which include: 1960,1967,1970,1976,1983,1986 and 1991. Considering an interpolation, it can be concluded that municipality of Crna Trava was exposed to $80-220 \mathrm{~mm}$ of precipitation for month July for selected years. Potential years for landslide activation were calculated by using The Precipitation Concentration Index (PCI), The Modified Fournier Index (MFI), and Lang Aridity Index (AILang).

Based on results from calculated values of PCI, MFI and AiLang indices (Fig 3), it can be concluded that the most critical years in term of precipitation were 1948, 1954, 1970, 1976, 1988, 2007, and 2014. Residents of the village of Bankovci were interviewed about previous disasters in these settlements and their confessions confirmed that extreme floods and landslides occurred also in: 1948, 1970, 1976, and 1988.

Corine Land Cover shows that broad-leaved forest, transitional woodland-scrub, natural grassland presents the $89,9 \%$ of the vegetation cover (Fig 4). High percentage of forest coverage could help preventing landslides.

After analyzing the precipitation from 13 precipitation stations that are shown in fig 5 , next step was finding their correlation to landslide occurrences. About 70\% of Crna Trava municipality lies on elevation above $1000 \mathrm{~m}$, in mountain area, which include Bankovci village. Bankovci village represents the starting point. Three landslides were activated on 25th of July 2018 in Bankovci village caused by extreme weather conditions, which affected wider region in Central and South-east Serbia: 100 liters of rain fell during the threehour period. Those landslides are located on road between Bankovci and Ruplje village. 


\section{A) $\mathrm{PCl}$}

Babušnica$$
25
$$

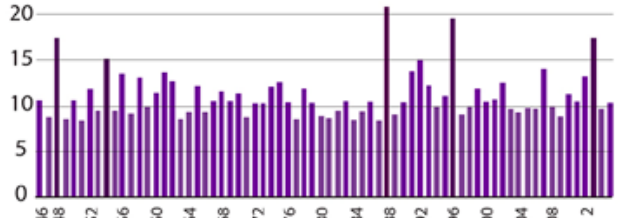

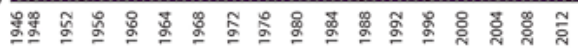
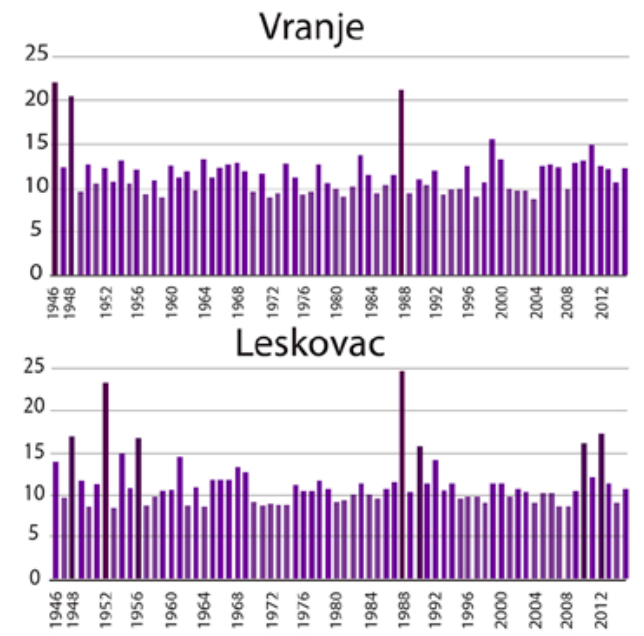

B) MFI

Babušnica
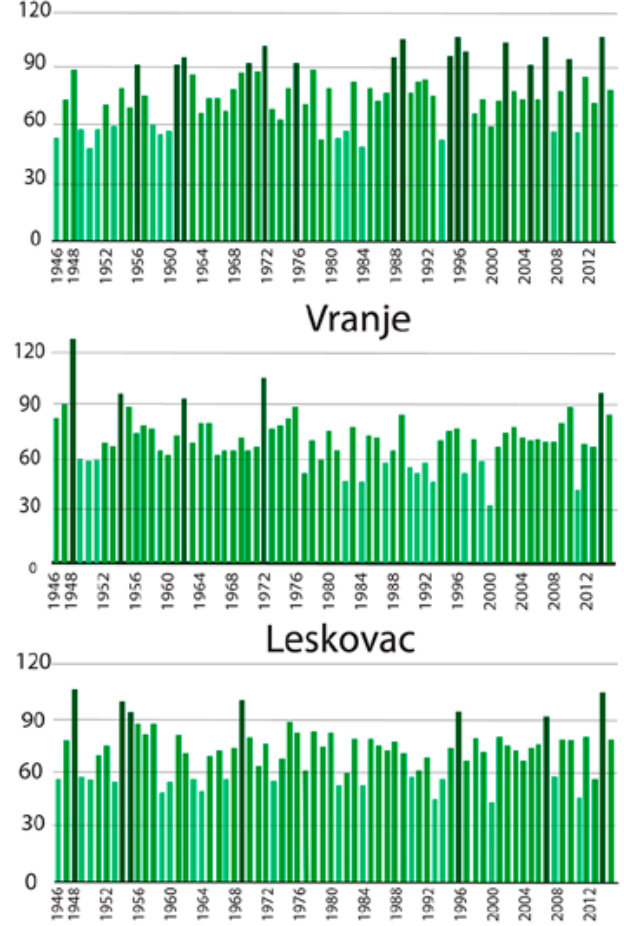

C) AlLang

Babušnica
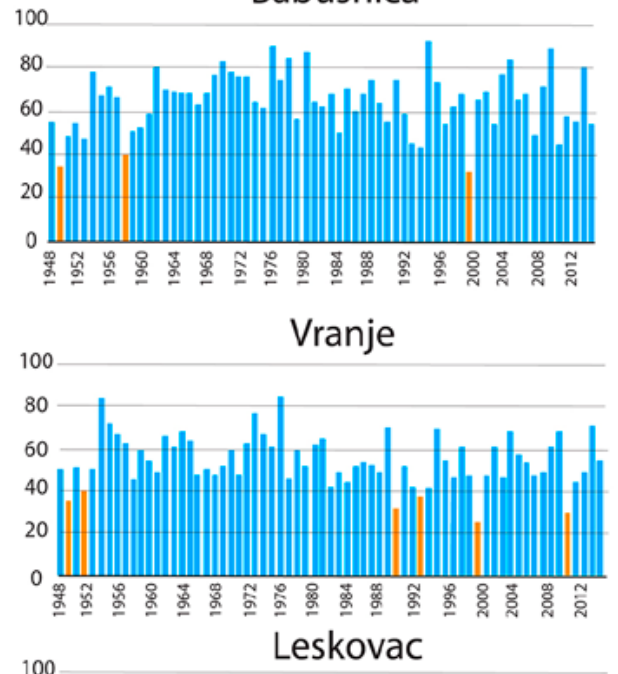
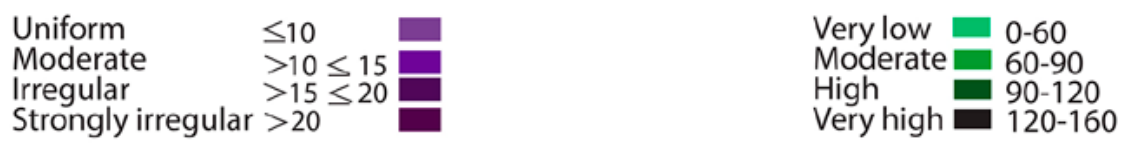

Figure 3. A) PCI, B) MFI and C) AILang indices for Babušnica, Leskovac and Vranje meteorological stations, and their classification for the past seven decades 
A) 1960

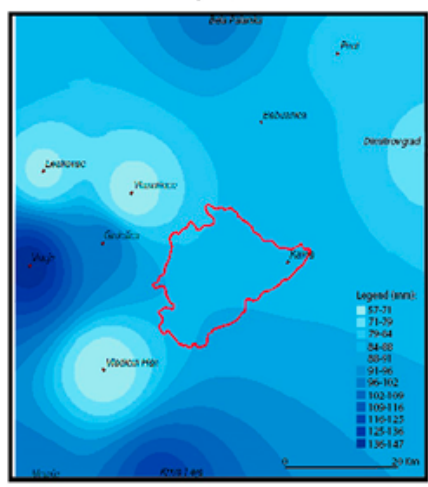

E) 1983
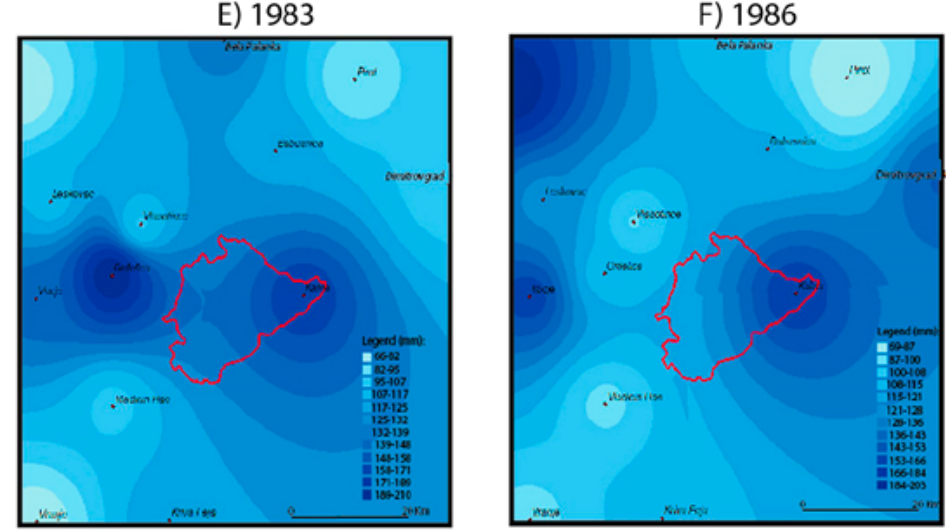

B) 1967

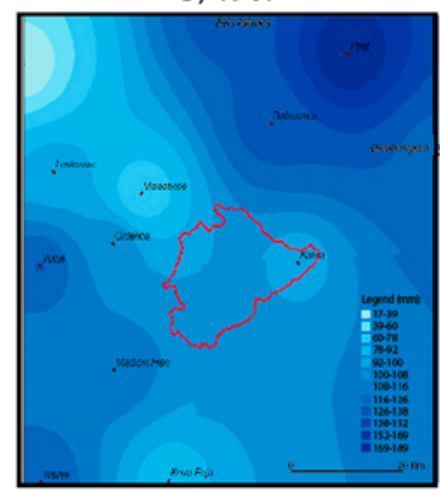

F) 1986

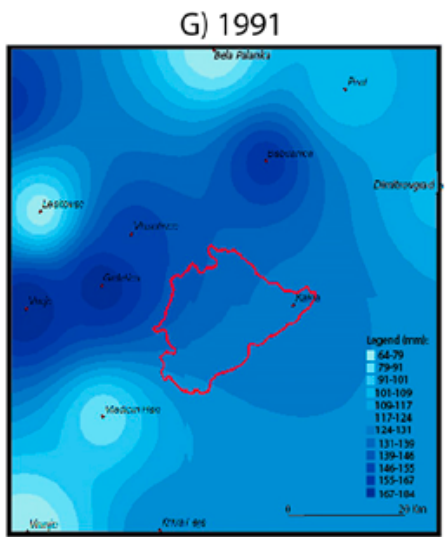

C) 1970

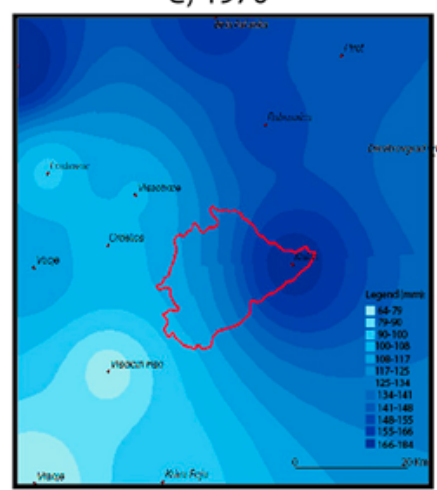

G) 1991
Figure 4. IDW interpolation of precipitation data from 13 precipitation stations in July around Crna Trava municipality. Chosen years had the highest precipitation rates in the last seven decades: A) 1960, B) 1967, C) 1970 D) 1976, E) 1983, F) 1986, and G)1991. There are geographical coordinates and elevation of each station. 
Pastures

Complex cultivation patterns

Agriculture + natural veg.

Transitional woodland-scrub

Broad-leaved forest

Corniferous forest

Mixed forest

Natural grassland

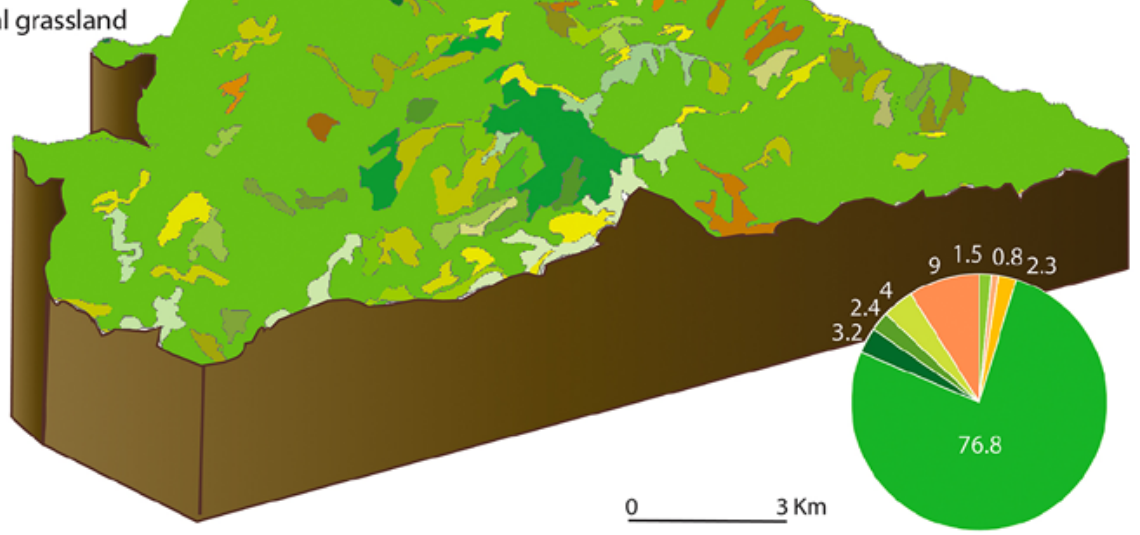

Figure 5. Corine Land Cover of municipality of Crna Trava in the year 2012 and percentages per class (\%)
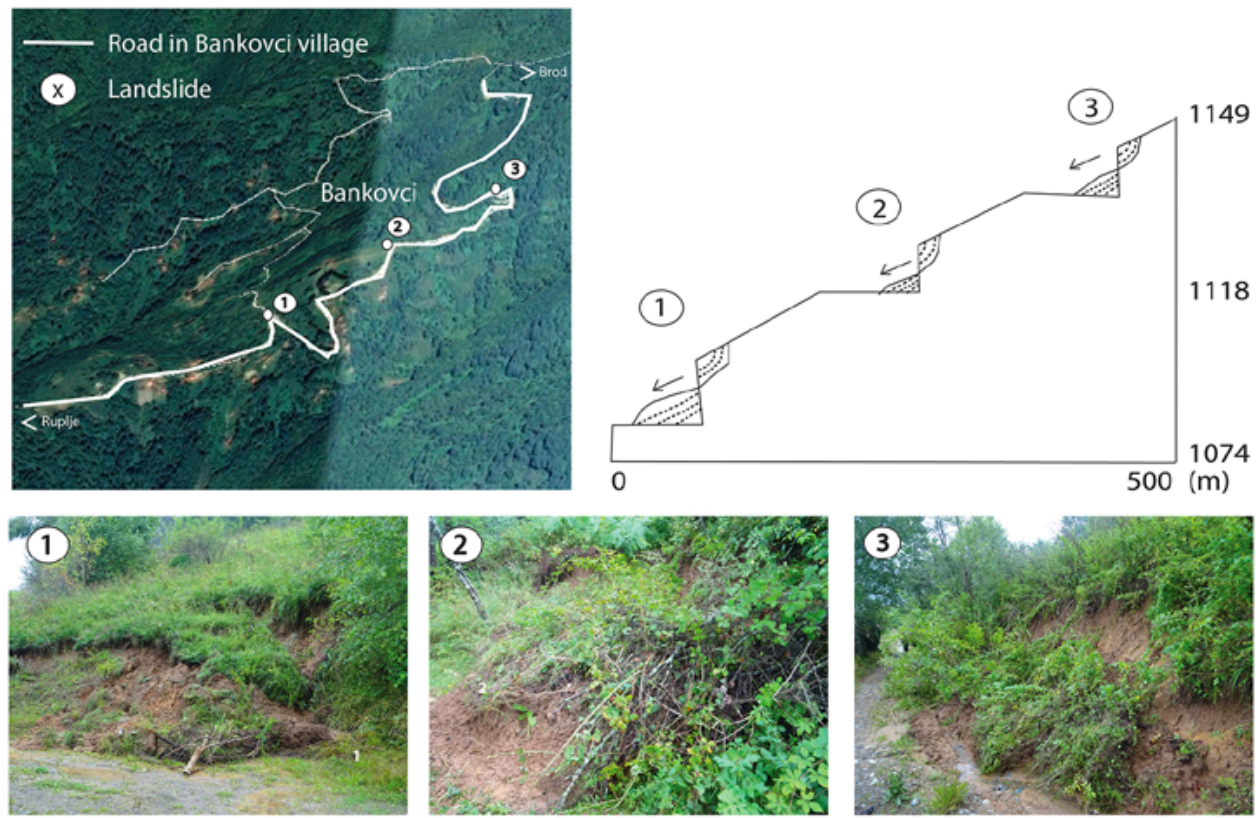

Figure 6. Landslides locations exported in Google Earth Pro, and their photos from fieldwork 
Their coordinates were loaded from GPS and exported into Google Earth Pro. Landslide locations can be seen in Fig 6 .

Almost every part of this settlement was exposed to some form of risk. The geology of Crna Trava is presented by various Paleozoic volcanic and metamorphic rocks: albite-chlorite-muscovite shales, albite-gneiss, albite-chlorite shales and porfiric biotiteamphibolic dacite. Geologic factors together with climatic factors resulted in intensive pedogenesis where in some parts solum is over $2 \mathrm{~m}$ thick, and thus prone to landslides.

Next step was finding correlations between exported coordinates of landslides and slope map of CrnaTrava and Bankovci village. The consequences of the weather variabilities were manifested in the highest proportions in the area of Bankovci village and the transit lines that connect Bankovci with the surrounding settlements.

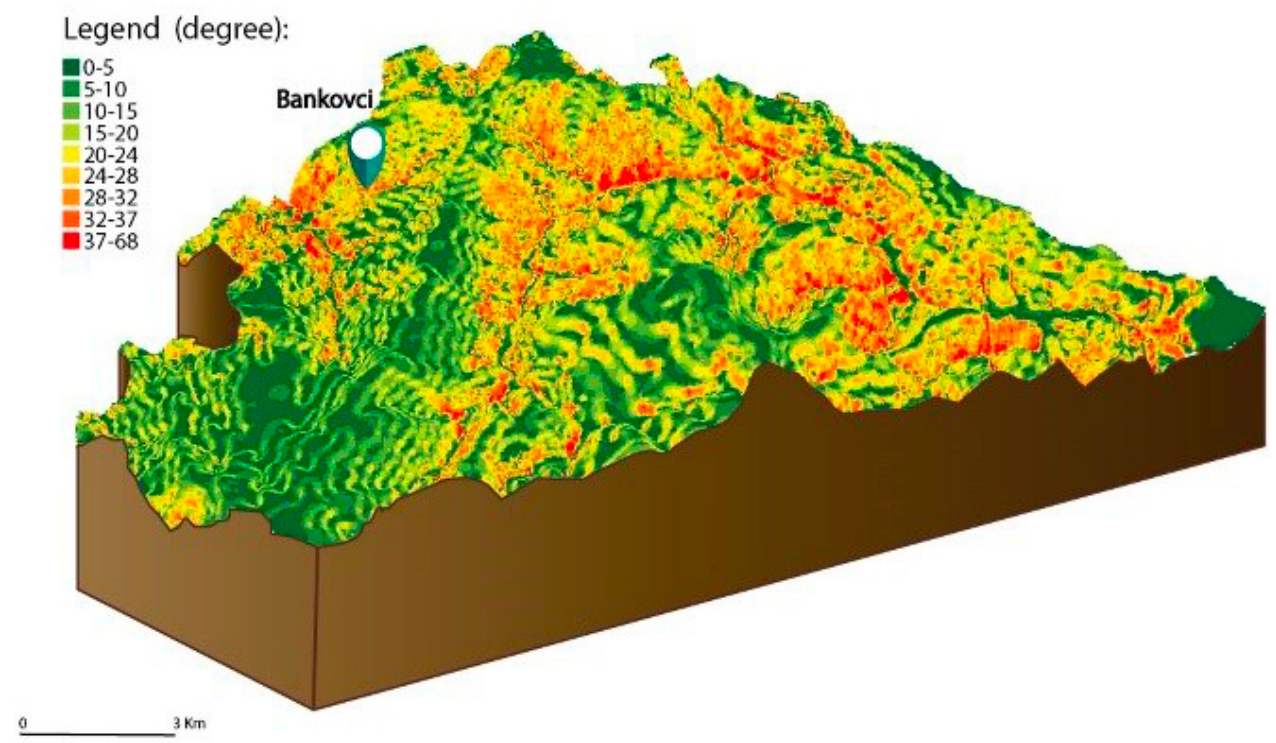

Figure 7. Slope analyses on municipality of Crna Trava (degree)

The tilt of 30 degrees and over that is the ideal condition for landslide formation (Fig 7). Orange and red color show the slopes of the terrain of 30 and over 30 degrees. Slope map of Bankovci village can be seen on Fig 8 and Fig 9. There are some main differences between maps. Households in Bankovci village are shown in Fig 8 and marked as pink dots and position of landslides that occurred on 25. of July.

In the comparation of Fig 6 and Fig 8, those landslides lie in red and orange zones on slope map. Many houses and roads in this area has disappeared for certain reasons, so the analysis is based on houses and roads that exist now. The village of Bankovci has below 100 households and most of them are abandoned. Model shows that $46 \%$ of households are in orange and red zones, which leads to a high risk of landslides formation in populated areas. Also, nearly $45 \%$ of the roads that are diminished on daily bases are also located in the potential landslide zone. 


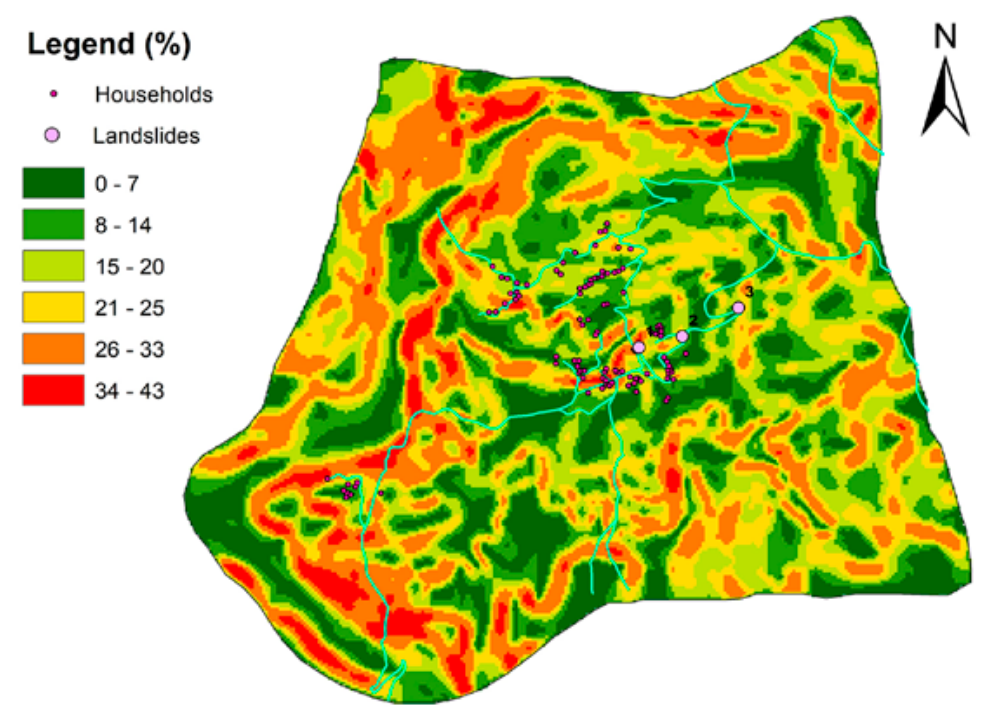

Figure 8. Slope analyses on Bankovci village (\%)

The roads case is represented on Fig 9. Blue color represents roads that exist now based on Google Earth Pro and ArcMap online sources. Purple color represents roads that existed in 1973 based on Topographic map for Vlasotince section. Areas framed in red represent those parts of the road that no longer exist. These areas are in the zone of potential landslides. Can it be said that these roads have certainly disappeared under the influence of landslides that have been driven? Such a conclusion requires a complex analysis of this area, but the slope of the terrain has played an important role in the degradation of the former roads. The consequences of this year's extreme July precipi-

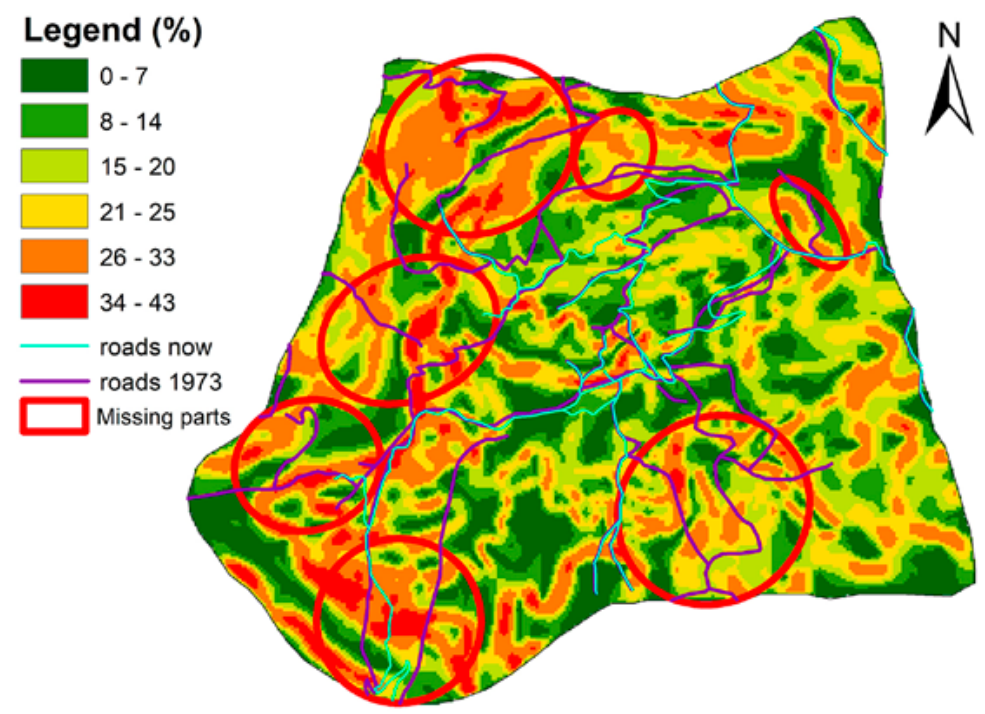

Figure 9. Slope analyses on Bankovci village focused on now not existing roads (\%) 

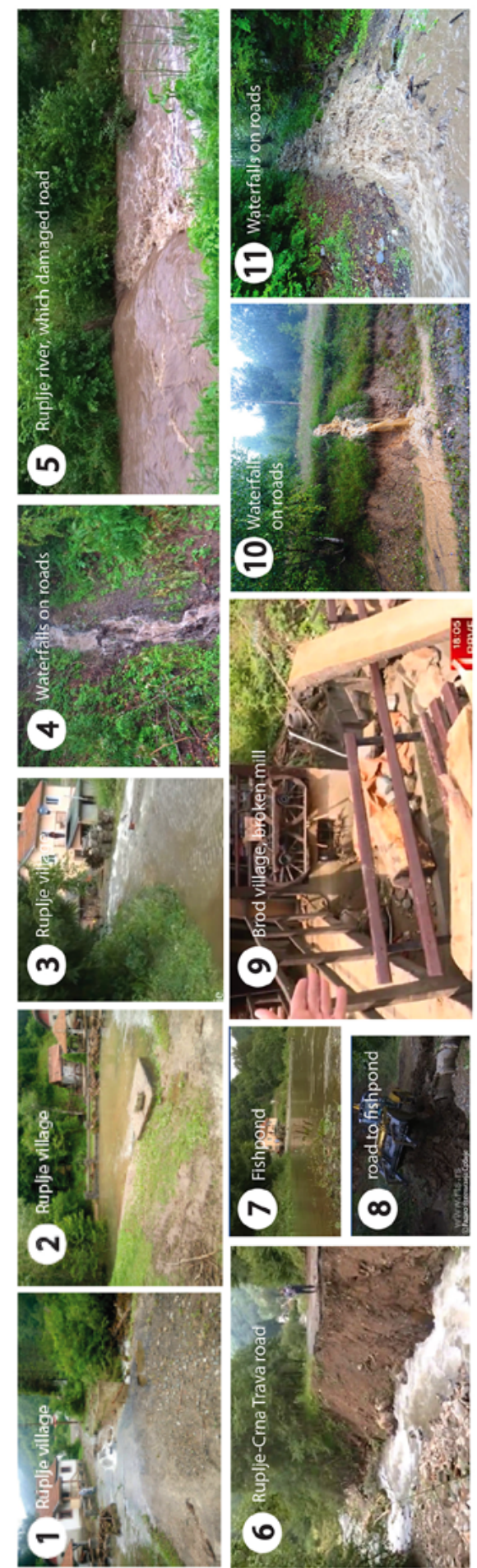

tation damaged the municipal budget for dozens million dinars and can be seen in Fig 10.

The most demolished parts of the Crna Trava municipality were the fishpond of Dobro Polje village $(7,8)$, mill in Brod village (9), numerous households, regional road Crna Trava-Ruplje-Predejane $(4,6,8,10,11)$, road Bankovci-Brod, and bridge on Ruplje River from Bankovci to Ruplje (1).

\section{CONCLUSION}

Several methods have been used to determine past extreme July precipitation and consequences they left in the least developed municipality of Crna Trava, Serbia. The consequences of extreme July precipitation in 2018 damaged the municipality budget for dozens million dinars. The most demolished parts of Crna Trava municipality were the fishpond of Dobro Polje and Ruplje village, mill in Brod village, regional road Crna Trava-Ruplje-Predejane, road BankovciBrod, bridge on Ruplje River from Bankovci to Ruplje and numerous households. The inhabitants of these regions say that such disasters have occurred only in 1948 in such proportions. It is clear that municipality of Crna Trava is highly sensitive to climate variability. The example of Bankovci village plays an important role. The settlement Bankovci is largely abandoned, as well as the large number of houses in the municipality of Crna Trava. The case study was done based on fieldwork which happened in a period from 20. to 26. July 2018 in the village of Bankovci where detected potential locations were visited, which explains the extreme precipitation of July and its conse- 
quences. But this is not the only time in the year when these areas are endangered and at a high-risk level. Since these are the most uninhabited areas in Serbia, whenever there is any kind of disaster, local authorities react late. The flow of information between the major centers in Serbia and these regions is alarmingly slow. The inhabitants of these areas remain isolated and trapped in their households for days of life-threatening foodstuffs, after the first major snow or heavy precipitations that collapse in the rainy seasons of the year. On 25 of July 2018, after 3 hours of precipitation, three exits from the village Bankovci were no longer existed. The roads Bankvci - Brod - Crna Trava, road Ruplje - Pavličine - Obradoce - Crna Trava and road Bankovci - Ruplje were completely destroyed up by torrential currents. The fact that there were no human casualties is the only positive occurrence in last year's July event. Due to the geological composition and topography of the terrain, as well as climatic conditions, it is possible to anticipate the activation of the landslide in the future.

\section{REFERENCES}

Abolmasov, B., Milenković, S., Marjanović, M., Đurić, U., Jelisavac, B. (2015). A geotechnical model of the Umka landslide with reference to landslides in weathered $\mathrm{Ne}$ ogene marls in Serbia. Landslides, 12(4), 689-702.

Aleotti, P., Chowdhury, R. (1999). Landslide hazard assessment: summary review and new perspectives. Bulletin of Engineering Geology and the environment, 58(1), 2144.

Apaydin, H., Erpul, G., Bayramin, I., Gabriels, D. (2006). Evaluation of indices for characterizing the distribution and concentration of precipitation: a case for the region of Southeastern Anatolia Project. Turkey: J Hydrol,328(3):726-732.

Census of Population, Households and Dwellings in the Republic of Serbia (2011). Migrations-Data by municipalities and cities. Belgrade: Statistical Office of the Republic of Serbia.

De Luis,M., Gonzalez-Hidalgo, J.C., Brunetti, M., Longares, L.A. (2011). Precipitation concentration changes in Spain 1946-2005. Nat Hazards Earth Syst Sci, 11(5):12591265.

De Luis, M., González-Hidalgo, J.C., Longares, L.A., Štepánek, P.(2009). Seasonal precipitation trends in the Mediterranean Iberian Peninsula in second half of 20th century. Int J Climatol, 29(9):1312-1323.

Dragićević. S., Filipović, D., Kostadinov, S., Ristić, R., Novković, I., Zivković, N., Andjelković, B., Abolmasov, V., Djurdjić, S. (2011). Natural hazard assessment for land-use planning in Serbia. International journal of environmental research, 5(2), 371-380.

Fournier, F. (1920). Climat et érosion: la relation entre l'érosion du sol par l'eau et les précipitations atmosphériques. Presses universitaires de France,551.302.

Kirschbaum, D., Stanley T. (2018). Satellite Based Assessment of Rainfall Triggered Landslide. Hazard for Situational Awareness, Earth’s Future, 6(3), 505-523. 
Kitanović, S.D. (2015). Demographic changes in the settlements of the municipality of Crna Trava in the second half of the XX and the beginning of the 21st century. Niš: Faculty of science.

Lazarević, R. (2000). Klizišta. Beograd: Društvo bujičara Jugoslavije.

Lang, R. (1920). Verwitterung und Bodenbildung als Einführung in die Bodenkunde. Stuttgart: Chweizerbart Science Publishers.

Lukić, T., Bjelajac, D., Fitzsimmons, K. E., Marković, S. B., Basarin, B., Mlađan, D., Sipos, G. (2018). Factors triggering landslide occurrence on the Zemun loess plateau, Belgrade area, Serbia. Environmental earth sciences, 77(13), 519.

Marjanović, M. (2009). Landslide susceptibility modelling: a case study on Fruška gora Mountain, Serbia. Geomorphologia Slovaca et Bohemica, 10.

Marković, J., Pavlović M. (1995). Geographical regions of Yugoslavia. Belgrade: Contemporary Administration.

Petley, D. (2012). Global patterns of loss of life from landslides. Geology, 40(10), 927-930.

Quan, C., Han, S., Utescher, T., Zhang, C., Liu, Y. S. C. (2013). Validation of temperature-precipitation-based aridity index: Paleoclimatic implications. Palaeogeography, Palaeoclimatology, Palaeoecology, 386, 86-95.

Radaković, M.G., Tošić, I., Bačević, N., Mladjan, D., Gavrilov, M.B., Marković, S.B. (2017). The analysis of aridity in Central Serbia from 1949 to 2015. Theor. Appl. Climatol., 1-12.

Van Westen, C. J., Van Asch, T. W., Soeters, R. (2006). Landslide hazard and risk zonation-why is it still so difficult?. Bulletin of Engineering geology and the Environment, 65(2), 167-184.

Varnes, D. J. (1981). Slope-stability problems of circum-Pacific region as related to mineral and energy resources.

http://geoliss.mre.gov.rs/OGK/RasterSrbija/ (accessed 25 March 2019)

http://www.hidmet.gov.rs/ciril/meteorologija/klimatologija godisnjaci.php (accessed 25 March 2019) 